\title{
MELTING AND METASOMATISM IN UPPER MANTLE PERIDOTITE XENOLITHS FROM LABAIT, NORTH- CENTRAL TANZANIA, AND CONTRASTING METASOMATIC STYLES IN THE TANZANIAN LITHOSPHERIC MANTLE
}

\section{J.B.Dawson}

Department of Geology and Geophysics, University of Edinburgh, Edinburgh EH9 3JW, United Kingdom

Labait ( $4^{\circ} 34^{\prime} \mathrm{S}, 35^{\circ} 26^{\prime} \mathrm{E}$ ) is a small Quaternary scoria cone with an associated lava flow, that lies adjacent to the major nephelinite/carbonatite volcano Hanang at the southern tip of the Gregory Rift Valley in North-Central Tanzania. The scoria and lava contain garnet-bearing and garnet-free peridotite xenoliths. Geothermometry of the garnet peridotites (Dawson et al. 1977) indicates a higher geothermal gradient beneath this part of the Gregory Rift, than further east in the Mozambique Belt and on the Tanzania Craton. Further, compared with primitive mantle (Taylor and McLellan,1985) the garnet peridotites are depleted in $\mathrm{Si}, \mathrm{Ti}, \mathrm{Al}, \mathrm{Ca}, \mathrm{Na}$ and $\mathrm{K}$, but contain higher concentrations of $\mathrm{Nb}, \mathrm{Rb}, \mathrm{Th}, \mathrm{Pb}$, and $\mathrm{Ba}$, the implication being that they have undergone a depletion event followed by a cryptic metasomatic overprint.

The garnet-free peridotites are lherzolite, harzburgite and dunite with olivine (Fo87-90), enstatite (En90-92, $\mathrm{Al}_{2} \mathrm{O}_{3}$ 1.2-1.5 wt\%, $\mathrm{CaO}$ 0.5-1.0 wt\%), clinopyroxene $(\mathrm{Ca} /[\mathrm{Ca}+\mathrm{Mg}]$ 41.9-48.2), and spinel (s.l.) $\left(\mathrm{Cr}_{2} \mathrm{O}_{3}\right.$ 43-53 wt\%, $\mathrm{MgO} 10-14 \mathrm{wt} \%$, and some lherzolites and dunites contain texturally-equilibrated Ti-phlogopite ( $m g$ 91-92, $\mathrm{TiO}_{2} \sim 3.5 \mathrm{wt} \%, \mathrm{BaO}<0.4 \mathrm{wt} \%$ ). Some samples have veins and/or pools of glass adjacent to which primary olivines have serrated margins with euhedral protrusions into the glass; these margins are more magnesian (Fo92) and calcic ( $\mathrm{CaO}$ up to $0.25 \mathrm{wt} \%$ ) than olivine away from veins (Fo90, $\mathrm{CaO} 0.08 \mathrm{wt} \%$ ). Rims of peridotite mica protruding into melt patches are darker brown and richer in $\mathrm{TiO}_{2}(5.66 \mathrm{wt} \%)$ compared with the light-brown primary micas $(3.65 \%)$.

The glass patches and veins contain precipitated Ti-augite, high Ti-phlogopite $\left(m g\right.$ 80, $\mathrm{TiO}_{2}>9$ ${ }_{w t} \%$ ) and spinel, all containing less $\mathrm{Cr}$ and $\mathrm{Mg}$, but more $\mathrm{Fe}$ and $\mathrm{Ti}$ than their peridotite analogues; harmotome, two unidentified Ba-rich phases, perovskite and calcite also occur. The glasses also contain euhedral olivine grains that, because of their optical continuity with the euhedral protrusions from the primary olivines and high magnesian content (Fo92-93) are interpreted as relics of partially-melted primary olivine grains, rather than having been precipitated from the melts.

The glasses include high-FeO (11.8 wt. \%), high- $\mathrm{BaO}(18.5 \%)$ and high- $\mathrm{K}_{2} \mathrm{O}$ (13.3\%) varieties, and compositions may vary between veins and melt pockets within single specimens; vesiculation of some glasses and low analytical totals indicate dissolved volatiles.

Similar to the garnet-bearing peridotites at Labait, the mica-free spinel peridotites are depleted in $\mathrm{Si}$, $\mathrm{Ca}, \mathrm{Al}$ and $\mathrm{Na}$ but contain higher $\mathrm{K}, \mathrm{Rb}, \mathrm{Ti}, \mathrm{Nb}, \mathrm{Th}, \mathrm{Pb}, \mathrm{Zn}$ and $\mathrm{Ba}$ than primitive mantle, reflecting a similar sequence of having undergone an early depletion event, followed by a metasomatic overprint that is particularly highlighted by the formation of phlogopite. However, the presence of high $\mathrm{Ba}$ and most of the relatively-low $\mathrm{Ca}$ appears to be tied to melt formation. Although some glass compositions could be generated by melting of phases in the mica-bearing peridotites, there is a mass balance problem with $\mathrm{Ti}, \mathrm{Ba}$ and $\mathrm{CO}_{2}$ which must have been introduced during a second metasomatic event.

The absence of a major influx of $\mathrm{Ca}$ but significant $\mathrm{Ti}$ and $\mathrm{Ba}$ addition during the Labait metasomatic events contrasts with metasomatism observed in other Tanzanian peridotite xenolith suites in the Quaternary volcanics at Lashaine (Ridley and Dawson, 1975; Dawson, 1987; Rudnick 
et al., 1994) and Olmani (Jones et al., 1983; Rudnick et al., 1993) where $\mathrm{CO}_{2}$-rich fluids are believed to be the metasomatic agent, and at Pello Hill (Dawson and Smith, 1988) where the metasomatism results is due to injection of a silicate melt of potassic melilitite composition. Each have different and distinctive metasomatic signatures, indicating a variety of metasomatic effects and agencies in the Tanzania lithospheric mantle.

\section{References}

Dawson. J.B., 1987, Metasomatic harzburgites in kimberlitic and alkaline magmas: enriched restites and "flushed" Iherzolites, in Menzies M. and Hawkesworth, C.J., eds.,Mantle metasomatism: London, Academic Press, p.125-144

Dawson. J.B. and Smith, J.V., 1988, Metasomatised and veined upper mantle xenoliths from Pello Hill. Tanzania: evidence for anomaously-light mantle beneath the Tanzanian sector of the East African Rift Valley: Contributions to Mineralogy and Petrology, v. 100, p. 510-527.

Dawson, J.B., James, D., Paslick, C., and Halliday, A.M., 1997, Ultrabasic potasic low-volume magmatism and continental rifting in North-Central Tanzania: association woth enhanced heat flow. Russian Geology and Geophysics, v. 38 (Proc. 6th Internat. Kimberlite Conf, Novosibirsk 1995, Volume 1 Kimberlites, related rocks and xenoliths), p. 69-81.

Jones. A.P., Smith,J.V. and Dawson, J.B., 1983, Glasses in mantle xenoliths from Olmani, Tanzania: Journal of Geology, v. 91, p. 143-165.

Ridley, W.I. and Dawson, J.B., 1975, Lithophile trace-element data bearing on the origin of peridotite xenoliths, ankaramite and carbonatite from the Lashaine volcano, Tanzania: Physics and Chemistry of the Earth, v. 9, p. 559-570.

Rudnick, R.L., McDonough, W.F. and Orpin, A., 1994, Northern Tanzania peridotite xenoliths: a comparison with Kaapvaal peridotites and inferences of metasomatic reactions: Proc. Fifth Internat.Kimberlite Conf Araxa 1991, Vol. 1, p. 336-353.

Rudnick, R.L., McDonough, W.F. and Chappell, B.W., 1993, Carbonatite metasomatism in the northern Tanzanian mantle: petrographic ans geochemical characteristics: Earth and Planetary Sciience Letters, v. 114, p. 463-475.

Taylor SR and McLellan SM., 1985, The continental crust: its composition and evolution, Oxford, Blackwell, 312p. 